\title{
The Impact of Digital in Learning Spaces: An Analysis on the Perspective of Teachers in Higher Education
}

\author{
Pedro Silva \\ Escola Superior de Tecnologias \\ de Castelo Branco, Instituto \\ Politécnico de Castelo Branco, \\ Castelo Branco, Portugal
}

psilva@ipcb.pt

\author{
Luis Borges Gouveia \\ Universidade Fernando \\ Pessoa, \\ Porto, Portugal
}

Imbg@ufp.edu.pt

\begin{abstract}
The generalized use of Communication Networks and Information Technologies is nowadays a global phenomenon. It has multiple impacts on how to teach/learn and on the contexts in which this process takes place (the Learning Environments). These areas include Physical Learning places, Virtual Learning sites, Collaborative Learning Spaces, among others. These proposals provide new scenarios for the teaching/learning process, but their outlines are not well defined yet. A Learning Space requires a complex set of materials and human resources. Further and continued research is significant and justified by the relevance of Higher Education Institutions. The overall objective of the present research is to understand the perceptions of the Professors in their Learning Environments. In this context it has been considered relevant to gather opinions on the needs/priorities, utility, quality and sustainability, as a result of the use of Information and Communication Technologies (ICT) in the teaching/learning spaces.
\end{abstract}

Keywords: Learning Spaces, Learning Environments, Higher Education, Teaching and Learning, Information and Communication Technologies (ICT).

\section{Introduction}

A multitude of systems are currently available to on-line courses. Its appreciation is related with the fact of providing the users a set of contents and functionalities in order to make easier the learning process. The success of this kind of systems has been, in the last decades, object of concern by investigators because of its huge sticking in academic, business and social world. The Bologna process (signed in June 1999, implies each university's system rearrangement in order to

Material published as part of this publication, either on-line or in print, is copyrighted by the Informing Science Institute. Permission to make digital or paper copy of part or all of these works for personal or classroom use is granted without fee provided that the copies are not made or distributed for profit or commercial advantage AND that copies 1) bear this notice in full and 2) give the full citation on the first page. It is permissible to abstract these works so long as credit is given. To copy in all other cases or to republish or to post on a server or to redistribute to lists requires specific permission and payment of a fee. Contact Publisher@InformingScience.org to request redistribution permission. create the Europe of Science and knowledge.) submission, while bringing in a new reorganization of the Portuguese higher education system, aims to encourage people to go to the university, to improve the teaching and learning quality and to encourage the Portuguese students' mobility. The e-learning platforms and the virtual learning environments have an increasing role in the higher education organizations. Current- 
ly in Portuguese higher education systems, almost all or even all the universities and Polytechnic Schools have in their web space an available e-learning platform to support the learning process in order to improve the training quality and to allow the creation of access terms and learning to other potential new users.

At the beginning this systems or websites were just simple stores of text contents, or books that supported classes, which were used by the student to access, read and learn. This kind of applications are changing, many of these systems allow the tutors to comprise, for instance, notes, recommendations, presentations, etc. These applications are becoming more sophisticated. This incorporated learning environments offer to students and teachers a new system to communicate, learn and exchange knowledge.

The great majority of the universities have insufficient or inappropriate learning spaces; they are too small, very dark or cold, made in the wrong places, etc. These places have many deficiencies and so, they waste learning opportunities. While managing these places, the central role these issues have in the teaching and learning process are not taken into account by the managers. The localization, the design and the learning spaces quality of construction, in the higher education system, are a differentiation factor among institutions.

A Learning Space requires a complex set of materials and human resources. A further and continued study is justified by the relevance of Higher Education Institutions. The overall objective of the present research is to understand the perceptions of the Professors in their Learning Environments. In this context it has been considered relevant to gather opinions on the needs/priorities, utility, quality and sustainability, as a result of the use of Information and Communication Technologies (ICT) in the teaching/learning spaces.

To find new ideas about space needs represents a significant opportunity for higher education to make learners and learning more successful [1]. So, the results obtained with this investigation focused primarily on perceptions related to Learning Environments, the needs of space, the adoption of ICT in learning spaces and the type of spaces used their needs and gains.

\section{Data and Research Methods}

The purpose of the perceptions of Learning Environments was to capture a set of personal experiences related to spaces used by teachers, particularly the "classroom", collaborative spaces, social spaces and virtual spaces. The main contribution of this study is to facilitate the creation of new Learning Environments and make a discussion of space's organization as one of the important factors in the creation of a learning space. The main ideas and conclusions (resulting from the interviews to the teachers of Higher Education) contribute towards the need to make changes.

All the interviews in this study were tape-recorded with the teacher's permission, and later transcribed to provide accurate records for the analysis. Standard procedures were followed to maintain the confidentiality of the interview data and the anonymity of the teachers. The interviews were structured around a list of topics (Figure 1) based on concepts presented in the existing literature, including sharing preferences with regard to the type of information, the person or group with whom the information is being shared, and the purpose behind sharing.

We asked research questions that were open, and focused on the list of topics to collect the perceptions. Our research questions for the first topic (Perceptions of Learning Environments) were: Q1 - "Let's talk about learning Spaces, space of classroom, collaborative space, social space and virtual space. From your experience as a teacher what is meant by each of these spaces?". 


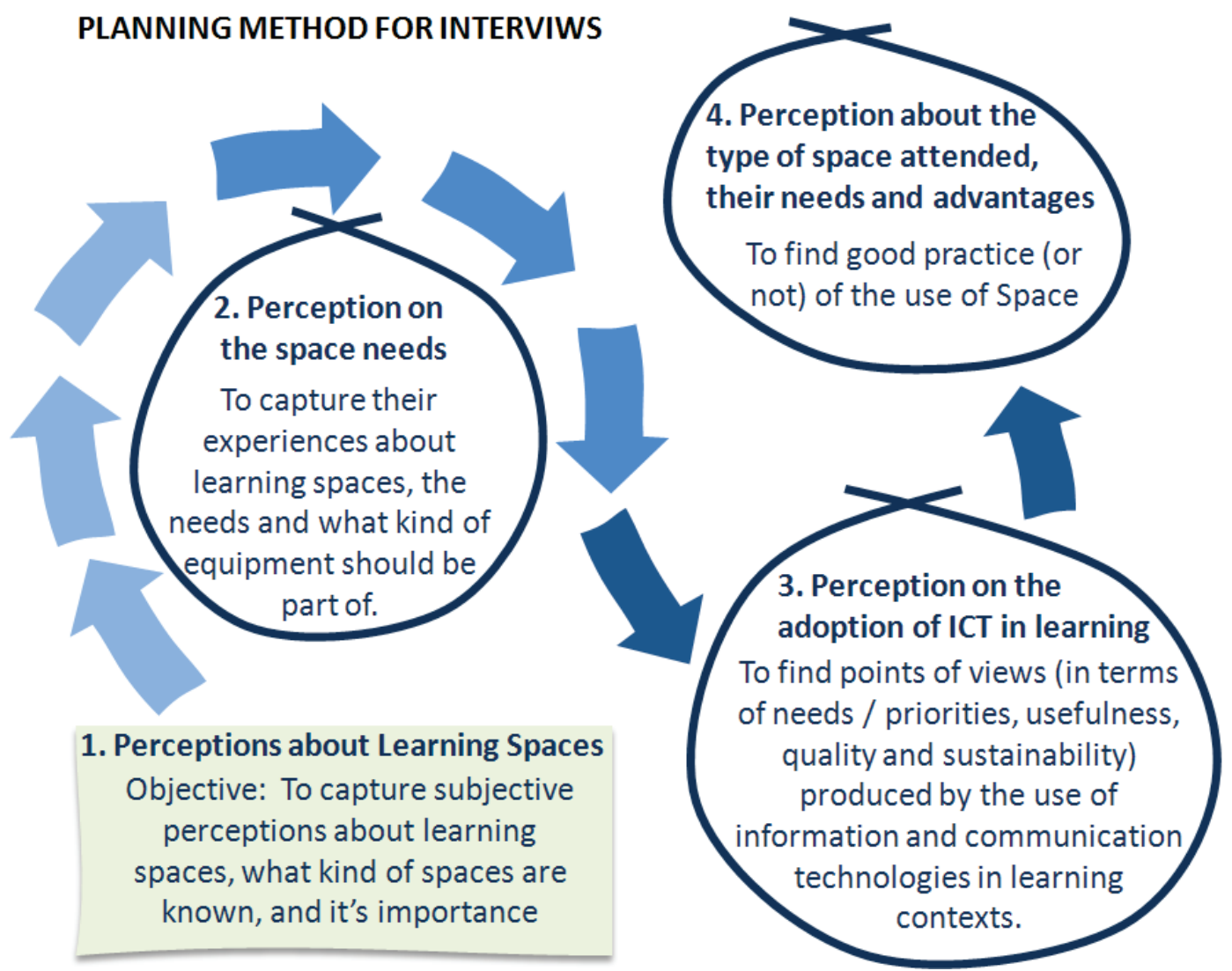

Figure 1: Planning method

For the second topic (Perception on the space needs) we asked: Q2 - "What do you think about an ideal learning space?" Q3 - "If you were asked to design a learning space, what aspects would you find relevant to consider?"

On the third topic (Perception on the adoption of ICT in learning) we used: Q4 - "In your opinion what is the role of Information and Communication Technologies in the quality of learning and the interaction with the learning space."

The fourth topic (Perception about the type of attended space, their needs and advantages) was: Q5 - Tell me how you feel about: "What do you enjoy most in this School?"; "What do you not enjoy in this School / learning space?"; "What do you think about the use of space in this school?"; "What would you like to see changed in the future?"

The interviews were engaged in a series of decision-making sessions regarding the number of teachers to interview and how to select them to participate in this study.

A criterion sampling scheme has been used to select teachers for the interviews. The followed criterion is shown in Figure 2. 


\section{Criterion sampling}

To select teachers for the interviews

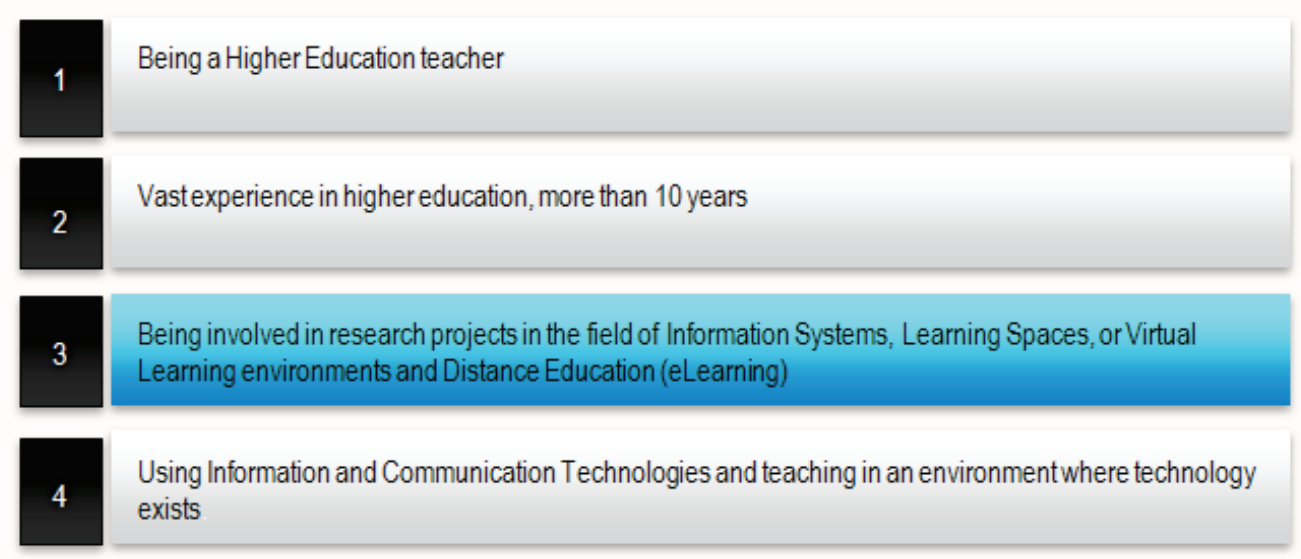

Figure 2: Criterion sampling

The interviews were face-to-face. Between the first and second interviews, almost three months passed. Based on our previous research experience, interviewing teachers, we felt a second interview was required to build a theory. A strong rapport was necessary to obtain trustworthy data.

The analysis of data was as follows. First the participants were assigned identification numbers. Audio-taped interviews were verbatim transcribed, checked for accuracy and edited by the first author, to ensure that the transcriptions reflected the actual interviews, by simultaneously listening to the recordings while reading the transcriptions and making corrections where necessary.

\section{Results and Discussion}

This investigation suggests many positive consequences and different points of view on the Best Practices about the use of teaching/learning spaces. To structure the principal findings that have been obtained to understand the perceptions of the Professors on their Learning Environments, we will use four separated dimensions: (i) Perceptions of Learning Environments; (ii) Perception on the space needs; (iii) Perception on the adoption of ICT in learning; (iv) Perception about the type of attended space, their needs and advantages. (See Figure 3.))

\section{Perceptions of Learning Environments}

All teachers knew and used the mentioned spaces. The concept of learning spaces was often confused with the classroom. The Classroom was recognized by all participants in this study as the most important space and reference in any educational institution. They all share the idea that the classroom's space must change, because of the new teaching methodologies, the introduction of new ICT, and the new students. The concept of Collaborative Spaces is not new; most of the teachers consider it very important because “(...)it is impossible to work alone(...)”. Some of the participants recognize that the way students collaborate with each other is important. In the new society's model, known by the network society, collaboration and collaborative learning spaces must be a reality.

\section{"We all agreed that collaborative spaces must exist with all the needed resources (...)"}

The concept of Social Spaces was the most difficult to identify and characterize. Teachers had some difficulties distinguishing collaborative spaces and social spaces. Virtual Spaces were the 
most identified and referred. All teachers stated examples from the institutions they belong to. They all used and recommended such spaces. Several examples of Managing Learning Systems applications (LMS) and Virtual Learning Environments (VLE), exploring Open Source or developed by them, are refereed. They all work and provide a range of features, for teachers and students.

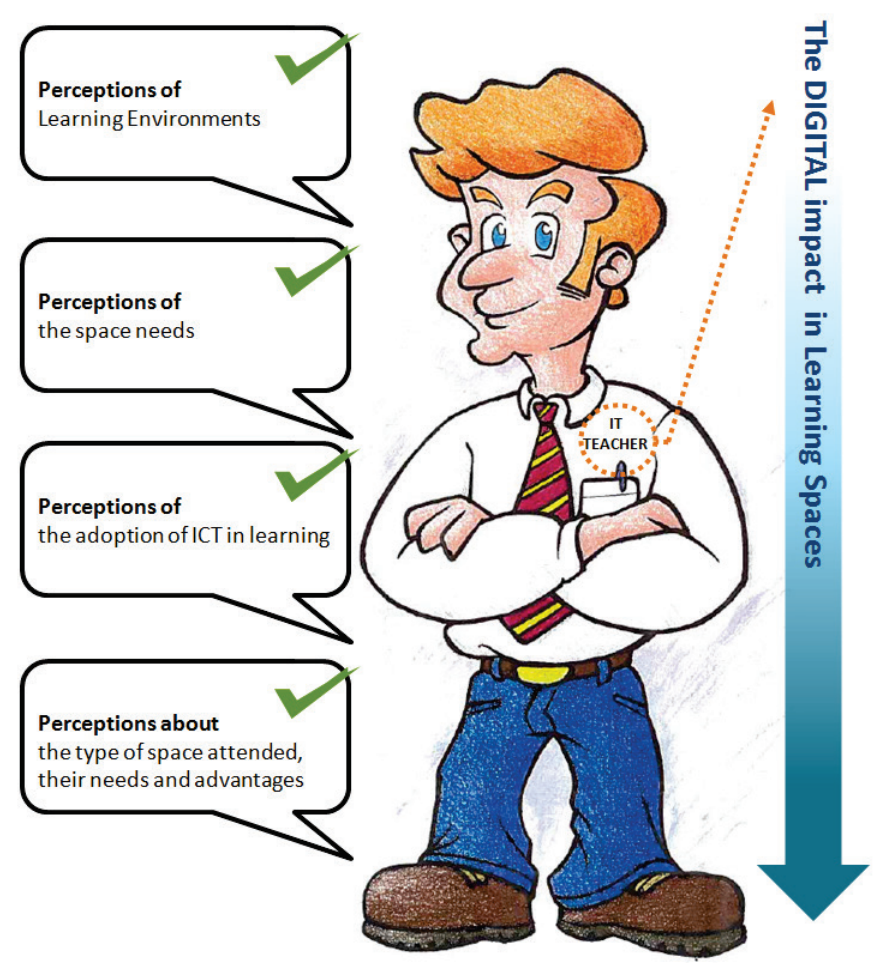

Figure 3: The Perceptions

One sentiment expressed with displeasure, was the fact that a better integration with the space and the classroom space is possible. "The potential of this is very limited, functioning as a repository of content". These spaces should, besides the educational environment to support the student's learning, also have other functions: personal tools to prepare classes, to support material, to perform administrative tasks, to seek information and materials and to be used as an interactivecommunication tool between teachers and educational partners.

\section{Perception of the Space Needs}

The main goal relating the space needs was to capture experiences about frequented learning spaces, what kinds of equipment and features should be part of. We asked respondents to characterize an ideal learning space and to identify aspects they think these spaces must have. Of all collected contributions there was a consensus across all participants, the models and the spaces in our higher education institutions do not meet the needs of students and teachers.

"The traditional classroom space is too limited, most of the time teachers are in a pulpit where knowledge flews in only one direction. Interaction between the teacher and students is almost impossible."

"This paradigm leads to changes in students and teachers attitudes (...)" 
"There was no change in teaching and of course there was no change in the classroom. (...)"

"It is important to create a psychological comfortable atmosphere between teachers and students in order to improve physical comfort."

"Learning in our universities is the "cod liver oil" meal. Education should be an intense and motivating experience as a good meal."

"The space organization and layout must follow that approach. The traditional classroom doesn't reflect the current paradigms. I remember university as being an inhospitable and uncomfortable place. I often felt like running out. Therefore, this concept must change."

"Universities must have well-equipped rooms. Space must have a minimum comfort, and luxury does not mean comfort."

When we asked to characterize the importance of space in teaching and learning activities, all the individuals characterized space as one of the main factors influencing teaching and learning quality. The way we organize space influences the quality, the way we collaborate, interact and share knowledge.

We asked to make a projection of the Ideal Learning Space. All held that an ideal learning space needs technology, adjustable furniture, different teaching methodologies, perfect environmental conditions and motivation.

All respondents stated that the current Space is very far from the Ideal learning Space.

"This type of space does not cover teachers and students needs (...)", "it is important to create individual spaces for each student, the existence of open spaces, smaller learning spaces, classrooms with mobilization facilities and the creation of "activity islands(...)"

\section{Perception on the Adoption of ICT in Learning}

Information and Communication Technologies (ICT) brought to Learning Environments several improvements. We asked respondents what they think about the adoption of technologies in Learning Environments. They all use and consider them essential in the classroom, but they also mentioned several conditions that cause the inappropriate use of technologies. They also held that access, maintenance, management and integration in the classroom are important.

"The role of ICT is very important, but teachers must dominate them. More and more new technologies must be part of education (...)

"Total redefinition of the learning spaces surrounded by much technologies (...)”

"The role of ICT in learning process is important but only as an extension of instrumental capabilities at the service of the learning process."

On the other hand, the use of Internet, essential for search, collaboration and communication, also brings some problems. To use ICT in learning spaces we need network and permanent available technological resources that many universities don't have.

Respondents also reported the insufficient specialized resources (human, materials and network) to support technologies.

Institutions do not project the availability and technologies access to be used by teachers and students in learning spaces.

Difficulties related to technology access, maintenance, support and management in higher education institutions lead, despite its presence, to insufficient utilization. 
The use of Information and Communication Technologies (ICT) in Learning Environments is limited. Institutions don't have the necessary conditions so that they can be used as part of the individuals' learning process.

\section{Perception about the Type of Space Attended, Their Needs and Advantages}

Another important aspect of this study was to collect perceptions about the type of attended space. Was asked to each professor, based on their experience of teaching in a higher education institution, what they think about: (i) What he liked most in the space he attended, (ii) the less he liked, (iii) what he thought of the use of space in his school, and finally, (iv) the future perspective and what he would like to see changed.

With this approach, it is our intention to collect opinions about space use practices, experience, needs and advantages. Although, many of these issues and opinions have already been answered during the interview and considered pertinent to this approach, since they focus on the general aspects of institutions and select multiple perspectives of concrete realities of different Higher Education Institutions.

The answers were quite varied, since the realities were quite different from institution to institution. Some were younger and others older, but we found that in both cases the organization of space is poor and needs changes.

Difficulties in the use of space were clearly present, not only by the perceptions collected in the interviews, but also through the participant's observation of many kinds of spaces in these institutions.

By the analysis of participants' verbal and nonverbal language, it can be deduced that there is much to be done in terms of space in Higher Education. However, there were some aspects and some cases of good practices in the use of spaces that must be considered:

“(...) human relationship between people (between teachers and students), it is easy and makes a difference..."

(...) We also have an immersive environment (...) the psychological space in the university has to be a constructive space, emotionally constructive, which has to combat the toxic emotions (...) it looses energy for research and education. (...) the mental health of the institution, in a smaller scale - the mental health in the classroom.

"What pleases me most is to have space (...) and think that expansion is possible."

“(...) most of activities have to go out of what is traditionally a classroom(...) is a social space, and the provided spaces for group work and the possibility of them being performed(...)"

"There must be a smart design with open areas where teachers and students communicate and technology (...)"

When we asked about the perspective to the future and what they would like to see changed important contributes were also founded.

"The social spaces are not used much and we have few, we should have living common spaces between the various schools (...) to develop such teamwork across multidisciplinary teams, the type of work they will find in business."

“(...) we will need great imagination to prepare lessons that meet technology (...) so the technology "pulls" the quality of classes (...)" 
Another aspect that emerged from this study has to do with the teacher's role in this new reality. It seems evident that according to these new realities it is necessary to change attitudes and practices in order to obtain optimization, integration and development of knowledge. However, to make that possible a change in attitude, methodologies and the way of being and teaching is needed. Consequently, space will necessarily change.

\section{Conclusion}

This study considered the perceptions of the Professors on their Learning Environments. It was primarily focused on perceptions related to Learning Environments, the needs of space, the adoption of ICT in learning spaces and the type of spaces used, their needs and gains. Our Intent is to complement and expand the knowledge about space use in higher education. The results confirm our central hypotheses: firstly, the importance of Space in creating high quality Learning Spaces. Secondly, we found that technology's adoption is important but is not the only factor taken into consideration to create these spaces. Technology it's an important point in the creation of Learning Environments, but just by itself it does not bring significant changes. Changes in design comfort and Decoration and Cultural Change must be part of a Learning Space.

New areas, such as the collaborative learning spaces, should be considered in the organization. The changes in furniture design, comfort and decoration, how the materials are arranged and organized, seem to influence the teaching and learning processes. They are a fundamental part of higher education context where human beings can enhance their learning activities.

The cultural change, social spaces and informal learning environments, seem to be a key role to a good psychological environment and motivate the participation in school activities.

To create high-technology learning, technology-rich spaces, the use of Virtual as an available tool to teaching and learning and its necessary integration with the physical, seem to be essential.

A flexible learning space enables the student to make choices and to have some control over the time and place and, sometimes, also to make choices in the content of their learning.

Therefore, the present investigation focused on the influence of space and the use of Information and Communication Technologies (ICT) in the teaching/learning spaces. It was found that the digital has changed the educational space, the concept of space and time to teach. Changes in Design, Furniture, Decoration, Comfort and Cultural Change are essential to create high-technology learning spaces according to the needs of teachers.

\section{References}

Aceto, S., et al. (2007). E-learning for innovation, executive summary. Helios Yearly Report. European eLearning Observation System: Observing, Foresighting \& Reporting.

Aceto, S., Delrio, C., Dondi, C., Fischer, T., Kastis, N., Klein, R., Strauss, A., \& Corbin, J. (1994). Grounded theory methodology - An overview. In N. K. Denzin and Y. S. Lincoln (Eds.), Handbook of qualitative research. Thousand Oaks: Sage Publications.

Brown, M. (2005). Learning spaces. In D.G. Oblinger, D. \& J.L. Oblinger (Eds.)

Charmaz, K. (2000). Grounded theory: Objectivist and constructivist methods. In N. Denzin and Y. Lincoln (Eds.), The handbook of qualitative research (vol.2). New York: Sage Publications.

Dittoe, W. (2002). Innovative models of learning environments, in the importance of physical space in creating supportive learning environments. New York: John Wiley \& Sons. 
Fortin, M-F. (2000). O processo de investigação da concepção à realização. Décarie Éditeur, ISBN: 972838310X

Glaser, B., \& Strauss, A. (1967). The discovery of grounded theory: Strategies for qualitative research. New York: Aldine Publishing Company.

Gouveia, L. (1998). Uma proposta para avaliação e diagnostico medida por computador. $1^{\text {a }}$ Conferência sobre redes de Computadores - CRC'98. Universidade de Coimbra.

Gouveia, L. (2009). A virtual environment to share knowledge: A visualisation design to support collaborative learning (1st ed.). USA: VDM Verlag Dr. Muller.

Gouveia, L., Borges, M., \& Bairrão, M.(2007). Gestão da Informação na Biblioteca Escolar. 1. ed. Figueira da Foz: GestKnowing, 2007. v. 1. 193 p.

Hannah, G., \& Hannon, C. (2007). Their space: Education for a digital generation. London: Demos, ISBN: 1841801755 .

JISC. (2005). Designing spaces for effective learning, a guide to 21 st century learning space design. JISC eSpaces Study, University of Birmingham.

JISC. (2006). Evaluation Report Highlights, Innovating e-Learning. 2006 JISC eSpaces Study, University of Birmingham.

JISC. (2010). E-learning and pedagogy strand. JISC eSpaces Study, University of Birmingham.

Miller H. (2004). A view of changing campus, Herman Miller inc. in www.hermanmiller.com

Miller H. (2005). Creating a culture of sustainability - how campus are taking the lead Herman Miller inc. in www.hermanmiller.com

Miller, H. (2008). Making room for collaboration. Herman Miller Inc. in www.hermanmiller.com

Novelli, G. (1997). A sala de aula como espaço de comunicação - reflexões em torno do tema, Interface. Comunicação, Saúde, Educação v1, n1.

Oblinger, D. G. (2006). Learning spaces. Washington: Educause - ISBN 0-96728553-7-2 e-book.

Richard, K., \& Voloudakis, J. (2005). The future of networking education, information technology networking in higher education. Educause Center for Applied Research (ECAR) Study.

Silva, P. \& Gouveia, L. B. (2008). ED-MEDIA 2008, Learning Space. Junho 30 -Julho 42008 ISBN : 1880094-65-7

Silva, P. \& Gouveia, L. B. (2010). INTERTECH'2010, A Geração Digital no Novo Mundo Empresarial”. Março 07-10: Ilhéus, Brasil; ISBN : 978858912075-3

Strauss, A. and J. Corbin (1990). Basics of qualitative research: grounded theory procedures and techniques. Sage Publications.

Strauss, A., \& Corbin, J. (1998). Grounded theory methodology: An overview. In N. K. Denzin \& Y. S. Lincoln (Eds). Strategies of qualitative inquiry. Sage Publications.

Tinto, V. (2003). Taking student learning seriously: Rethinking the university of the future. In Charting the Course: Earl V. Pullias Lecture Series on the Future of Higher Education. 26th Annual, Fall Los Angeles - Center for Higher Education Policy Analysis, USC Rossier School of Education.

Valenti, M. (2005). Learning space design precepts and assumptions. EDUCAUSE Review, 40(4), (July/August 2005) 


\section{Biographies}

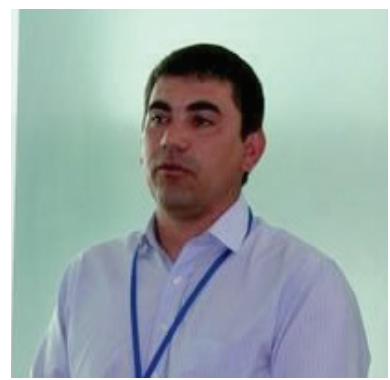

Pedro Silva is an Adjunct Professor in the Technical-Scientific Computing unit (UTC Informatics) of the Polytechnic Institute of Castelo Branco where he lectures in the fields of multimedia and humancomputer interaction. Pedro holds a degree in Computer Science from the University Lusfona (2000) Master degree in organization and information systems from the University of Evora (2005) and a Ph.D. in Information Sciences specialty in Systems and Information Technology from the University of Fernando Pessoa (2011). he shifted his research interests to Information Society (Information Systems and Information Management) new forms for education teach support (application of computer technologies in education, in particular, the use digital environments and impact space in higher education) and human-computer interaction.

Pedro has a Web homepage at http://www.est.ipcb.pt/pessoais/psilva/

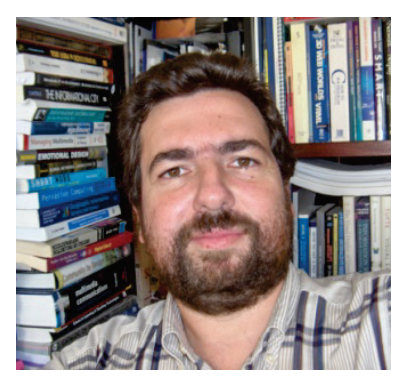

Luis Borges Gouveia is an Associate Professor at University Fernando Pessoa. He holds a PhD in Computer Science (University of Lancaster, 2002) and a Masters degree in Electronic and Computers Engineering (University of Oporto, 1995). His interests are within the impact of information society and digital use both in education and business.

Luis has a Web homepage at http://homepage.ufp.pt/ lmbg 